\title{
Staff Satisfaction with Workplace Facilities in the School of Environmental Technology, Federal University of Technology, Akure, Nigeria
}

\author{
Mbazor D.N. ${ }^{1}{ }^{1 *}$, Ajayi M.A. ${ }^{1}$ and Ige V.O. ${ }^{1}$ \\ ${ }^{1}$ Department of Estate Management, School of Environmental Technology, Federal University of Technology, \\ Akure, Nigeria \\ Corresponding Author: *dnmbazor@futa.edu.ng
}

\begin{abstract}
This paper presents the findings of the existing university infrastructural facilities (i.e. water supply, electricity supply, office facilities, faculty buildings, laboratory facilities and toilet/convenience facilities) in a representative sample of staff satisfaction with workplace facilities in the School of Environmental Technology, Federal University of Technology, Akure Nigeria. Published literatures have been analysed to review knowledge areas pertaining to workplace facilities and their contributions to organisational high productivity. Various workplace facilities evaluated in this study have been analysed to identify major areas of challenges for the faculty staffs' satisfaction. A user satisfaction survey was developed to obtain the staffs' qualitative feedback on their experience and satisfaction with the facilities provided in the faculty. The findings of the survey were analysed and reported to describe the level of satisfaction with the identified performance requirements for the workplace facilities. The main purpose of conducting the study was to determine whether or not the facilities provided at the workplace by the organisation provides the needed satisfaction to the working staff for optimum performance. This paper is of practical value to employers of labour whether private or public sectors, educational institutions, staff and students whose performance of duties are tied to the available facilities. University administrators involved in the provision of infrastructural facilities in the workplace should ensure that the provision and up-keep of the workplace enhancement requirements presented in this paper are properly addressed in the system.
\end{abstract}

Keywords: Environment, Facilities, Satisfaction, Staff, Workplace

\subsection{Introduction}

A workplace environment is the environment where people work together to achieve organizational goals. AbdulGhafoor and Tafique (2015) described environment as "systems, processes, structures and tools and all those things which interact with employees and affect in positive or negative ways on employees performance." Environment can also be defined as a particular location where task is done or completed. In relating the concept to employment, the work environment involves the physical geographical location as well as the immediate surroundings of the workplace such as a university environment, a construction site, a mechanic workshop or an office building. Workplace environment equally consist of other factors associated with the place of employment such as the quality of the air, noise, illumination levels, structural facilities and fringe benefits associated to employment such as free child care or unlimited coffee, or adequate parking or intangible benefits such as sponsored holidays.

It has been noted that infrastructural facilities are important to the overall organisational performance of universities. Besides the fact that such facilities provide a healthy learning environment for students, they are also expected to engender a safe and conducive working environment for the employees of the universities. Observably, however, most universities in sub-Saharan Africa mostly lag behind in the quality and quantity of infrastructural facilities provided for both staff and students 
(Amole, 2009). A number of studies have evaluated the perception of students on the facilities provided for them in their hostels, whereas not much research has been done on the perception of staff about the facilities provided for them (Adewunmi et al., 2011; Oluwunmi et al., 2012). Secondly, health challenges have been reported among staff of tertiary institutions that are related to their work environment. Furthermore, unconducive work environment leads to low productivity among university staff (Shantakumari et al., 2014; Sudaw et al., 2017).

Infrastructural facilities has for long been thought of as a crucial element of university campuses. Hassanain (2007) confirmed that universities worldwide have realized the contributions of infrastructural facilities towards achieving their objectives. According to the author, campus facilities operate as an integral component of the university which contributes significantly to the achievement of its overall goals and missions. Donald (1974) explained that infrastructures and facilities such as water, power, waste disposal, transportation or similar services are developed or acquired by public agencies such as universities to enhance their smooth operations and to facilitate the achievement of common social and academic objectives. Amole (2009) observed that most students in Nigeria universities are not satisfied with the facilities provided in both the faculty buildings and halls of residences, resulting to poor academic performances over the years.

The high prevalence of vision related problems among universities staff is an issue of great concern which is affecting the productivity of staffs in their work place. Despite this, research efforts to investigate the real sources of these challenges in the working environment of the staff are sparse. This study, therefore seeks to investigate staffs' satisfaction with workplace facilities in the School of Environmental Technology, Federal University of Technology Akure (FUTA), Nigeria.

\subsection{Literature Review}

The physical and social environments where students, particularly those in higher institutions receive training and learning are vital to ensure the derivation of highest level of benefit from education system. Parameters such as space arrangement, size of offices, classrooms, laboratories, number of users in a building, electricity, water, furniture and equipment, colour of paint used, hygiene, aesthetics, safety, heat, internet, sound and lighting conditions can be listed among the physical environment criteria for university facilities. Available research has shown that these conditions not only influence education activities but also have great influence on the social and communication behaviour of the users (Erbil and Sezer, 2016). Collet da Graca et.al (2007) studied environmental comfort conditions in education buildings. Garret (1981) suggests that acoustic, heat and temperature, size of spaces, lighting, and ventilation factors have an impact on the academic achievement of both staff and students. This study was corroborated by (Garret 1981, Wargocki and Wyon, 2007, Erbil and Sezer, 2016). On the other hand, Bako-Biro et al. (2012) noted that poor ventilation rates can have a negative impact on schoolwork performance and health of teachers and students.

Similarly, Edwards (1991) indicate that when physical conditions of school buildings improve the academic achievement of students also improve. Also, Overbaugh (1990) indicates that lecturers have lower efficiency when heating, cooling and ventilation problems exist in classrooms that are small and very crowded. Khedariet al. (2000) carried out studies on indoor air quality and ventilation. Avsar and Gonullu (2005), Elmallawany (1983) have studied on sound insulation, acoustic and noise. Kruger and Dorigo (2008) studied the impact of daylight and natural lighting and their finding revealed that these factors will make a positive impact in improving indoor physical environmental quality in educational facilities. Some researchers observed that it is not enough to just satisfy users but it is more important to ensure that users are extremely satisfied through the provision and effective maintenance of needed facilities in the system (Sivadass and Baker-Prewitt, 2000); Bowen and Chen, 2001).

Scholars have observed that the work place environment contributes to $24 \%$ in job satisfaction. It increases productivity level of an individual by $5 \%$ and team performance can be increased to $11 \%$ through developing good working environment (Arokiasamy, 2013). AbdulGhafoor and Tafique (2015) found that the factors like compensation, rewards, job security and good working environment increase level of commitment and sense of belonging with an organization. 
In a similar manner, Bakotic and Babic (2013) stated that working environment such as office size, power and water supply impacts on job satisfaction. The researcher further noted that employees prefer to work in working environment that is less risky. Also, Ollukkaran and Gunaseelan (2012) in their study found that how well employees engage with their working environment will have positive impact on employees' performance level. Also, office design and size are source of motivation by employees as observed by Amina and Shela (2009). Roelofsen (2002) in studying the impact of indoor environment, observed that indoor office environment has great impact on job performance and level of performance, which can be increased from 5 to 15 percent because of improving working conditions. Similarly, work place condition also impacts on employees' stress, of which Vischer (2006) noted that a good working environment will lead to better fit between work space and employees and results in improving behaviour and stress related emotions. It is equally observed that a good working environment changes employees approach towards job performance as according to Berg and Kalleberg (1999) job and overall working environment has substantial effect on workers and could help in balancing work and family life. Goudswaard (2012), in describing factors constituting a healthy working environment, highlighted work life balance, motivation level, psychological conditions, social dialogue, management and leadership coherence, transparency develop a good working environment and a good working environment leads to increased organizational productivity. Haynes (2008) found that the behaviour components of working environment have more impact than the physical components of working environment.

University environment is an environment where teaching and research activities are carried out simultaneously. Creating comfortable facilities in the university environment and maintaining them to ensure efficient performance will provide a supportive setting for a high quality education. Several studies have examined educational facilities but not from the angle of staff satisfaction (Boneh, 1982; Edwards, 1991; Clements-Croome et al., 2008). The number of studies examining university facilities from the point of view of staffs is relatively low. To this extent, this study is poised to seek to examine staffs' satisfaction with facilities provided in the School of Environmental Technology, Federal University of Technology Akure, thereby contributing to literature in the field knowledge.

The major focus in this research is to point out how satisfactory working environment can be created in the university working environment. The variables selected for study essentially relate to basic infrastructural facilities in a faculty building of university, an aspect of working environment which plays fundamental role in shaping a satisfactory and conducive working environment. The variables have been considered in the context of university environment which depend on the intellectual efforts of the employee for growth and progress of the institution. It is believed that the research results will guide university authorities in considering the influence facilities have on the overall performance of their academic staff in the discharge of their responsibilities.

\subsection{Materials and Methods}

The goal of this study is determining the parameters that influence work performance in the university building facilities from the viewpoint of both academic and non-academic staffs' satisfaction.

Primary data were used to conduct the research study. The primary source was through the use of questionnaire. The questionnaire was based on five point Likert scale. The staffs of the School of Environmental Technology were the target audience. Both academic and non-academic were considered in the study. Out of one hundred and eighty eight (188) staffs of the faculty, 100 staffs were purposely chosen and questionnaires were distributed to them across the seven departments in the School of Environmental Technology. Only 84 of the questionnaires were correctly filled and returned.

The cross-sectional descriptive study design was used to examine different variables of a working environment affecting performance and satisfaction of the employees in different departments in the School of Environmental Technology, Federal University of Technology Akure, Nigeria. After collection of primary data, coding was used to translate respondents' responses and to organize and summarize research data into manageable form. The questionnaire, which is based on a Likert type, was applied to 100 staff users in School of Environmental Technology building. The data collected 
were analysed by percentages, relative satisfaction index and weighted mean score, which were calculated using the formulas stated below:

$$
\begin{aligned}
& W M S=\frac{\left(5 n_{5}+4 n_{4}+3 n_{3}+2 n_{2}+n_{1}\right)}{N} \\
& R S I=\frac{\left(5 n_{5}+4 n_{4}+3 n_{3}+2 n_{2}+n_{1}\right)}{5 N}
\end{aligned}
$$

where:

WMS weighted mean score

RSI relative satisfaction index

$n_{5} \quad$ number of respondents who answer strongly agree

$n_{4} \quad$ number of respondents who answer agree

$n_{3} \quad$ number of respondents who answered undecided

$n_{2} \quad$ number of respondents who answer strongly disagree

$n_{1} \quad$ number of respondents who answer disagree

$N \quad$ total number of respondents

\subsection{Results and Discussion}

\subsection{Results}

Table 1 show the distribution and retrieval of questionnaires from the respondents which consist of both academic and non-academic staff of the School of Environmental Technology, Federal University of Technology Akure, Nigeria. The reason for administering questionnaires to both academic and non-academic staffs is because the two entities constitute the entire staff of the school under study. In all, 69 of the respondents were academic staffs which represent $82.2 \%$ of the sampled population while 15 which represent $17.8 \%$ of the respondents were the non-academic staffs.

\begin{tabular}{|c|c|c|c|c|c|c|}
\hline \multirow{2}{*}{$\begin{array}{l}\text { Respondents/ } \\
\text { Department }\end{array}$} & \multicolumn{2}{|c|}{$\begin{array}{l}\text { Number of questionnaire } \\
\text { administered }\end{array}$} & \multicolumn{2}{|c|}{ Number of questionnaire retrieved } & \multicolumn{2}{|c|}{ Percentage $(\%)$ of response } \\
\hline & $\begin{array}{l}\text { Academic } \\
\text { staff }\end{array}$ & $\begin{array}{l}\text { Non-academic } \\
\text { staff }\end{array}$ & Academic staff & $\begin{array}{l}\text { Non-academic } \\
\text { staff }\end{array}$ & Academic staff & $\begin{array}{l}\text { Non-academic } \\
\text { staff }\end{array}$ \\
\hline ARC & 11 & 3 & 11 & 2 & 16.4 & 13.3 \\
\hline BDG & 12 & 2 & 7 & 2 & 10.4 & 13.3 \\
\hline ESM & 13 & 3 & 12 & 3 & 17.9 & 20 \\
\hline IDD & 12 & 2 & 11 & 2 & 16.4 & 13.3 \\
\hline SGV & 12 & 2 & 6 & 2 & 9.0 & 13.3 \\
\hline QSV & 12 & 2 & 8 & 2 & 11.9 & 13.3 \\
\hline URP & 12 & 2 & 12 & 2 & 17.9 & 13.3 \\
\hline TOTAL & 84 & 16 & 67 & 15 & 100 & 100 \\
\hline
\end{tabular}

Table 1: Analysis of Administered Questionnaires

Source: Field survey, 2018

From the 82 respondents and as shown in the Table 2 below, there were 60 men and 22 women who took part in the survey. Their percentages were $73.2 \%$ and $26.8 \%$ respectively. As far as their level of education is concerned, 5 had Bachelors or HND certificates, 44 had Master's degree, 22 had Doctorate degree and 11 were professors. Their percentage distributions were $6.1 \%, 53.7 \%, 26.8 \%$ and $13.4 \%$ respectively. The respondents belonged to different age groups. Twenty seven (27) belonged to age group of 25-35 years, 37 were between 36-45 years and 18 respondents belonged to age group of 46 years and above. On the job experience among the respondents, $19.5 \%$ had job experience from 1 to 5 years, $35.4 \%$ had experience of 6 to 10years, $18.3 \%$ had $11-15$ years, $20.7 \%$ had $16-20$ years, $3.7 \%$ had $21-25$ years, $1.2 \%$ had 26 to 30 years and $1.2 \%$ of them had job experience of 31 years and above. The respondents belonged to seven (7) different departments in the faculty (see Table 1). These include 13 from Architectural Technology (ARC), 9 from Building Technology (BDG), 15 from Estate Management (ESM), 13 from Industrial Design department (IDD), 10 from Quantity Surveying (QSV), 8 from Surveying and Geo-Informatics (SGV) and 14 from Urban and Regional Planning (URP). 
Table 2: Socio-economic characteristics of the respondents

\begin{tabular}{|l|c|c|}
\hline Gender & Frequency & Percentage \\
\hline Male & 60 & 73.2 \\
\hline Female & 22 & 26.8 \\
\hline Total & 82 & 100 \\
\hline Level of education & 5 & \\
\hline Bachelors/HND & 44 & 6.1 \\
\hline Masters & 22 & 53.7 \\
\hline Doctorate & 11 & 26.8 \\
\hline Professors & 82 & 13.4 \\
\hline Total & & 100 \\
\hline Age & 27 & \\
\hline $25-35$ years & 37 & 32.9 \\
\hline $36-45$ years & 18 & 45.1 \\
\hline 46 years and above & 82 & 22.0 \\
\hline Total & & 100 \\
\hline Working experience & 16 & \\
\hline $1-5$ years & 29 & 19.5 \\
\hline $6-10$ years & 15 & 35.4 \\
\hline $11-15$ years & 17 & 18.3 \\
\hline $16-20$ years & 3 & 20.7 \\
\hline $21-25$ years & 1 & 3.7 \\
\hline $26-30$ years & 1 & 1.2 \\
\hline 31 years and above & 82 & 1.2 \\
\hline Total & & 100 \\
\hline Sour & & \\
\hline
\end{tabular}

Source: Field survey, 2018

From Table 3, it was observed that of all the factors that enhance work performance in the study area, availability of water supply within the faculty building is the most significant factor that enhances staff work performance in the organization. It has the highest weighted mean score of 4.73 and rank highest in the scale. Closely followed to water supply is the availability of toilets and places of convenience in the work environment which has a weighted mean score of 4.45. The result shows that availability of water supply within the faculty building is the most important factor that can enhance workplace satisfaction among the studied staff in their work environment.

Table 3: Facilities that enhance workplace performance in Universities

\begin{tabular}{|l|l|c|c|c|c|c|c|c|}
\hline S/N & Factors & SA & A & N & D & SD & $\begin{array}{c}\text { Weighted } \\
\text { Mean }\end{array}$ & Rank \\
\hline 1 & Availability of water supply & 68 & 10 & 1 & 2 & 1 & 4.73 & 1 \\
\hline 2 & Toilet \& convenience facilities & 54 & 22 & 2 & 3 & 1 & 4.45 & 2 \\
\hline 3 & Adequacy of lecture\& laboratory rooms & 23 & 54 & 2 & 1 & 2 & 4.15 & 3 \\
\hline 4 & Size of staff offices & 8 & 29 & 12 & 18 & 15 & 2.96 & 4 \\
\hline 5 & Office facilities \& equipment & 4 & 10 & 11 & 18 & 49 & 2.17 & 5 \\
\hline 6 & Electricity supply & 1 & 3 & 1 & 41 & 36 & 1.68 & 6 \\
\hline 7 & Location of buildings in relation to other uses & 0 & 4 & 1 & 12 & 65 & 1.12 & 7 \\
\hline
\end{tabular}

SA - Strongly Agreed; A - Agreed; N - Neutral; D - Disagreed; SD - Strongly disagreed

Source: Field survey, 2018

Table 4 below shows the satisfactory level of some selected workplace facilities among the respondents of the study area. The study revealed that the respondents are satisfied with the internet connectivity, aesthetic nature of the workplace and nature of ventilation/indoor air quality in their workplace, which have relative satisfactory indexes of $0.92,0.78$ and 0.75 respectively. The study further revealed that health and safety issues in the workplace is considered less significant as it has only 0.44. The implication of this is that majority of staffs of the School of Environmental Technology, Federal University of Technology Akure (FUTA) do not prioritize the issue of health and safety in the choice of their workplace. 
Table 4: Analysis of respondents' satisfaction level with workplace

\begin{tabular}{|l|l|c|c|c|c|c|c|c|}
\hline S/N & Responses & VS & S & N & D & VD & RSI & RANK \\
\hline 1. & Internet connectivity & 62 & 14 & 1 & 4 & 1 & 0.92 & 1 \\
\hline 2. & Aesthetics of work place & 28 & 34 & 6 & 13 & 1 & 0.78 & 2 \\
\hline 3. & Ventilation/indoor air quality & 27 & 31 & 2 & 9 & 13 & 0.75 & 3 \\
\hline 4. & Health safety of workplace & 9 & 3 & 5 & 45 & 20 & 0.44 & 4 \\
\hline
\end{tabular}

VS - Very satisfied; S - Satisfied; N - Neutral; D - Dissatisfied; VD - Very dissatisfied Source: Field survey, 2018

\subsection{Discussion}

From the above results, it can be seen that adequate office space in a workplace leads to increase in staff productivity. The result is in line with Garret (1981), Wargocki and Wyon (2007) and Erbil and Sezer (2016) who opined that size of spaces, lighting, and ventilation factors have an impact on the academic achievement of both staffs and students. Good power and lighting condition were helpful in developing the workplace that enhances staff productivity. The result of this study is in agreement with the study conducted by Kruger and Dorigo (2008) that studied the impact of daylight and natural lighting in a workplace environment and found that proper lighting of the workplace creates optimum comfortable condition for users. Similarly good and hygienic work environment such as functional toilet and convenient facilities are also helpful in developing a favourable working environment that has positive impact on employees' productivity. The results agree with that of Goudswaard (2012) who described factors constituting a healthy working environment to include adequate hygiene, motivation level, psychological conditions, social dialogue and a good working environment as they lead to increase organizational productivity. The results are also in line with Ajala (2012) who argued that working in an environment is considered to be conducive aids the productivity of workers in such an organization.

\subsection{Conclusion}

Drawing from the above analysis and findings, a conclusion can be drawn to the effect that workplace environment is helpful in increasing employees' level of productivity. Factors like adequate office space, good indoor and outdoor air quality, availability of water, power, toilets, and health and safety facilities are helpful in developing a workplace environment that has positive impact on employees' level of productivity in an organization. The results also send a message to organizations especially universities and other educational institutions that by developing a conducive environment, the level of employees' productivity can be increased and maintained.

In this regard it is very important to define the issues that staffs are discontent with to establish design criteria for faculty buildings to be designed in the future and to establish main goals for the planning of the university in general. Factors that influence staff satisfaction should be taken into consideration in university building designs for the future.

Given the resources available to the researchers in undertaking this study, only $53.19 \%$ of the population was issued questionnaire. The questionnaires actually used in data analyses were 84 representing $44.68 \%$ of the original population. This sample size may affect the generalization of the findings of this study. However, for the sample analysed in the course of this work, the findings are valid.

As the employees play important role in the progress of academic and research efforts and a lot of time and resources are required to train and retain the employees and to equip them according to future challenges, developing a conducive working environment is a crucial issue faced by universities. The study has highlighted the importance of good and efficient workplace environment. The findings recommend the organizations to develop strategies which are useful in developing a conducive working environment at the workplace.

Finally the study recommends that universities must observe continuously the dynamic nature of the environment under which people work with a view to enhancing workers satisfaction. Universities 
must also ensure the sustenance of aesthetics workplace environment to ensure a harmonious and conducive working environment. There should be adequate water supply in faculty buildings to enhance good hygiene and sanitary environment. Lastly, universities should endeavour to put in place an efficient and good health and safety plans to ensure employees' safe and healthy workplace for greater productivity.

\section{References}

AbdulGhafoor, A. and Tafique, T. (2015). Impact of working environment on employee's productivity: A case study of Banks and Insurance Companies in Pakistan. European Journal of Business and Management, 7(1), pp. 145-157

Adewunmi, Y., Omirin, M. and Famuyiwa, F. (2011). Post-Occupancy evaluation of postgraduate hostel facilities. Facilities, 29(3/4), pp. 149-168

Ajala, E. (2012). The influence of workplace environment on workers' welfare, performance and productivity. The African symposium: An online Journal of the African Educational Research Network, 12, pp. 141-149

Amina, H. and Shela, A. (2009). Impact of office design on employees' productivity. A case Study of Banking Organisations of Abbotttabad, Pakistan. Journal of Public Affairs, Administration and Management, 3(1), pp. 62-71

Amole, D. (2009). Residential satisfaction in students' housing. Journal of Environmental Psychology, 29 , pp. 76-85.

Arokiasamy, A. R. A. (2013). A study on employee satisfaction perspectives in the hotel industry in Malaysia. International Journal of Management and Strategy, 4(6), pp. 78-93

Avsar, Y. and Gonullu, M. T. (2005). Determination of safe distance between roadway and school buildings to get acceptable school outdoor noise level by using noise barriers. Building and Environment Journal, 40(9), pp. 1255-1260

Bako-Biro, Z., Clements-Croome, D., Kochhar, N., Awbi, H. and Williams, M. (2012). Ventilation rates in schools and pupils' performance. Building and Environment, 1(48), pp. 215-223

Bakotic, D. and Babić, T. (2013). Relationship between working conditions and job satisfaction: The Case of Croatian Shipbuilding Company. International Journal of Business and Social Science, 4(2), pp. $98-102$

Berg, P. and Kalleberg, A. (1999). The role of the work environment and job characteristics in balancing work and family. Paper presented at an Economic Policy Institute symposium on June 15, 1999. The symposium was funded by grants from the United States Department of Labour and the Alfred P.Sloan foundation.

Boneh, M. (1982). Environmental comfort in educational buildings - influence of windows and other openings. Energy and Buildings, 4(3), pp. 239-243

Bowen, J. T. and Chen, S. L. (2001). The relationship between customer loyalty and customer satisfaction. International Journal of Contemporary Hospitality Management, 13(5), pp. 213-217

Clements-Croome, D. J., Awbi, H. B., Bako-Biro, Z., Kochhar, N. and Williams, M. (2008). Ventilation rates in schools. Building and Environment, 43(3), pp. 362-367

Collet da Graca, V. A., Kowaltowski, D. C. C. K. and Diego Petreche, J. R., (2007). An evaluation method for school building design at the preliminary phase with optimization of aspects of environmental comfort for the school system of the state São Paulo in Brazil. Building and Environment, 42(2), pp. 984-999 
Donald, C. S. (1974). Professional education in public works/environmental engineering administration, $5^{\text {th }}$ ed. Chicago American Public Works and Association.

Edwards, M. (1991). Building conditions, parental involvement and student achievement in the D. C. public school system. Unpublished Master Degree Thesis, Georgetown University, Washington, D.C

Elmallawany, A. (1983). Field investigations of the sound insulation in school buildings. Building and Environment, 18(1-2), pp. 85-89

Erbil, Y. and Sezer, S. (2016). User satisfaction of environmental quality in university buildings. European Journal of Sustainable Development, 5(3), pp. 476-488

Garret, D. M. (1981).The Impact of school building age on the academic achievement of high school pupils in the State of Georgia. Unpublished Doctoral Dissertation, University of Georgia, USA

Goudswaard (2012). Flexibility and working conditions: a qualitative and comparative study in Seven EU Member States.

Hassanain, M. A. (2007). Post-Occupancy indoor environmental quality evaluation of student housing facilities. Architectural Engineering and Design Management, 3(4), pp. 249-256

Haynes, Barry (2008). The impact of office comfort on productivity. Journal of Facilities Management, 6 (1), 37-51

Khedari, J., Yamtraipt, N., Prantintong, N. and Hirunlabh, J. (2000). Thailand ventilation comfort chart. Energy and Buildings, 32(1), pp. 245-249

Kruger, E. L. and Dorigo, A. L. (2008). Day lighting analysis in a public school in Curitiba, Brazil. Renewable Energy, 1(33), pp. 1695-1702

Ollukkaran, B. A. and Gunaseelan, D. R. (2012). A study on the impact of work environment on employee performance. International Journal of Management Research, 2(2), pp. 71-85

Oluwunmi, A.O, Akinjare, O.A. and Izobo-Martins, O.O. (2012). User's satisfaction with residential facilitiesin Nigerian private universities: A study of Covenant University. Transnational Journal of Science and Technology, 2(11), pp. 93-112

Overbaugh, B. L. (1990). School facilities: The Relationship of the physical environment to teacher professionalism. An unpublished doctoral dissertation, Texas A\&M University.

Roelofsen, P. (2002). The impact of office environments on employee performance: The design of the workplace as a strategy for productivity enhancement. Journal of Facilities Management, 11(3), pp. 247-264.

Shantakumari, N., Eldeeb, R., Sceedharan, J. and Gopal, K. (2014).Computer use and vision related problems among University students in Ajman, United Arab Emirate. Annals of Medical and Health Sciences Research, 4(2), pp. 258-263

Sivadass, E. and Baker-Prewitt, J. L. (2000). An examination of the relationship between service quality, customer satisfaction, and store loyalty. International Journal of Retail and Distribution Management, 28(2), pp. 73-82

Sudaw, L., Tepanata, P., Karl, J.N. and Ngamjit, K. (2017). Effectiveness of a participatory eye care program in reducing eye strain among staff computer users in Thailand. Risk Management and Healthcare Policy. Available online at: 
https://www.ncbi.nlm.nih.gov/pmc/articles/PMC5436759/pdf/rmhp-10071.pdf (accessed May, 2018)

Vischer, J.C. (2006). The concept of workplace performance and its value to managers. California Management Review, 49(2), pp. 62-79

Wargocki, P. and Wyon, D. P. (2007). The effects of outdoor air supply rate and supply air filter condition in classrooms on the performance of school work by children. HVAC\&R Research, 13(2), $165-191$ 